\title{
GRASSROOTS SOLIDARITY IN REVITALISING RURAL ECONOMY IN ASIA, DRAWING LESSONS FROM THREE CASE STUDIES IN INDIA, INDONESIA AND CHINA ${ }^{1}$
}

Denison Jayasooria ${ }^{2}$

\begin{abstract}
As Asia is experiencing rapid economic development, it is also impacted by both positive and negative aspects. Rapid urbanisation and the growth of mega cities in Asia is impacting the quality of life of the poor in these cities as well as impacting negatively the rural areas and abandoned farming land. However within Asia are grassroots community experiences which are revitalising the rural economy through community organising, women empowerment and creative interventions through sustainable business models and good governance principles. Three case studies highlighted from India, Indonesia and China to illustrate this and draw lessons from transforming our economic priorities toward social solidarity economy.
\end{abstract}

Keywords: Rural development, solidarity economy, community based businesses.

\section{SOLIDARIEDADE POPULAR NA REVITALIZAÇÃO DA ECONOMIA RURAL NA ÁSIA, TIRANDO LIÇÕES DE TRÊS ESTUDOS DE CASO NA ÍNDIA, INDONÉSIA E CHINA}

\section{Resumo}

A Ásia tem apresentado um rápido desenvolvimento económico, mas este apresenta tanto aspectos positivos quanto negativos. A rápida urbanização e o crescimento das megacidades na Ásia tem gerado impacto na qualidade de vida dos pobres nestas cidades, assim como nas zonas rurais e nas terras agrícolas abandonadas. No entanto, na Ásia, são experiências comunitárias de base que estão a revitalizar a economia rural através da organização comunitária, do empoderamento das mulheres e de intervenções criativas através de modelos empresariais sustentáveis e de princípios de boa governança. Esta análise dispõe de três estudos de caso destacados da Índia, Indonésia e China para ilustrar e apresentar lições da transformação das nossas prioridades económicas quanto á economia social solidária.

Palavras-chave: Desenvolvimento rural, economia solidária, empresas de base comunitária

\footnotetext{
${ }^{1}$ This paper presents an expanded and revised version of that previously published in REVITALISING RURAL ECONOMY - SSE ASIA.

2 Presidente do Conselho Asiático de Economia Solidária (ASEC) e membro do Conselho da RIPESS global. Ex-Professor de Advocacia Pública do Instituto de Estudos Étnicos da Universidade Nacional da Malásia (UKM). E-mail: denisonkitaukm@gmail.com.
} 


\section{SOLIDARIDAD DE BASE EN LA REVITALIZACIÓN DE LA ECONOMÍA RURAL EN ASIA, SACANDO LECCIONES DE TRES ESTUDIOS DE CASO EN INDIA, INDONESIA Y CHINA}

\section{Resumen}

El rápido desarrollo económico de Asia también se ve afectado por aspectos positivos y negativos. La rápida urbanización y el crecimiento de las megaciudades en Asia están afectando a la calidad de vida de los pobres en estas ciudades, así como a las zonas rurales y a las tierras de cultivo abandonadas. Sin embargo, en Asia hay experiencias comunitarias de base que están revitalizando la economía rural a través de la organización comunitaria, el empoderamiento de las mujeres y las intervenciones creativas mediante modelos empresariales sostenibles y principios de buena gobernanza. Esta análisis destaca tres estudios de caso de India, Indonesia y China para ilustrar esto y presentar lecciones de la transformación de nuestras prioridades económicas hacia la economía social solidaria.

Palabras clave: Desarrollo rural, economía solidaria, empresas comunitarias

\section{INTRODUCTION}

Asia encompasses 53 countries and 5 billion people which is $60 \%$ of the world population. It is the fastest growing countries and has a robust economy. It has a rich ethnic, cultural, linguistic and religious diversity. It has vast geographical landscape. At the same time it has major problems with poverty, inequality, major cases of human rights violations as well as environmental and climate change issues.

Urbanisation in Asia is on an upward trend with large mega cities in most Asian countries, however the rural population varies by country to country. In this context, three Asian countries are among the countries with the largest populations in the world namely China (1.4billion), India (I.3billion) and Indonesia (273 million) (World Meter, 2020). It can also be noted that the rural population is still significant in these three countries in East Asia, South Asia and South East Asia for example in China it is $39.2 \% \%$, India it is $65 \%$ and in Indonesia it is $45 \%$

This upward trend towards urbanisation and reduction of the rural population is a major concern to government in this region. Most countries have introduced development policies to improve the quality of life as well as improved job opportunities in rural location.

It is significant to note that there are calls to reverse urbanisation in Asia. The question is "why urbanisation is deemed crucial to global development?" (Nair, 2013). Here the 
problem is that many governments are investing more into urban development as compared to the rural. The call is "to strengthen rural development, to make the villages and townships that still house most Asians places that offer decently paid work and support proper education, health and cultural infrastructure. It is about reversing policies that empty the country and discount its economic value".

One Asian critic is Singaporean academician and architect, Tay Kheng Soon who writes about the western idea of development which is a concept of "ultimate triumph of urbanism, western-style, and the ultimate triumph of urban economy" (Tay, 2008). He further calls this the "urbanist development ideology of the West"(Tay, 2008). His call is for "a new opportunity to shift the development agenda to include the rural and urban as a single space" (Tay, 2008). He also develops the idea of "rubanisation" which is where distinctions between country sides and cities are dissolved. It is also similar to the idea of rurbanomics which is "an approach that emphasizes the linkages between the rural and urban economies" (Steiner \& Fan, n.d.). The development policy agenda is that both urban and rural economies are important and equal partners. This balance is urgently needed in the context of climate change issues on the one hand and other urban affluent issues such as obesity. Therefore a holistic approach of health and agriculture where urban folks begin to value the agricultural production from rural areas.

In this development approach is also one of investing sufficiently in the rural areas to also improve the living conditions as well as the governance and accountability mechanism. This will ensure better quality of life where there is also good potential for employment and income generation.

The Asian Solidarity Economy Council (ASEC, 2O19) hosted a two day International conference on Transformative Economy in Yogyakarta, Indonesia on Nov $12 \& 13,2019$. The Conference was attended by 40 participants from eight Asian countries. The theme of this Conference was Revitalising Rural Economy through Social Solidarity Economy. This conference was organised to draw lessons from grassroots community based initiatives within Asia which are undertaking alternative economic models from the ground upwards by community based initiatives as well as civil society led community projects.

Two of the three case studies presented here were discussed at the ASEC 2019 Yogyakarta conference. All three case studies discussed in this chapter are illustrative of what the rural grassroots are doing in Asia in reviewing the rural-urban trend and through multi- 
stakeholder partnerships between grassroots movements, local government and private sector in seeking to improve the quality of life of the people especially in rural areas.

Case study one is from South India in Tamil Nadu where rural villagers organise themselves as cooperatives in over a 1,000 villages where they collectively utilise their energy and produce from the rural areas. Whether it is agricultural produce or animal husbandry, there is collective action by the families in the villages. In the case of the raising of livestock, the rearing of cows and milking by individual families but collective action by them to collect the milk, transport it to cooperative owned milk factories and finally distribution for retail selling.

Case study two is a village close to the city of Jogjakarta, Indonesia where many of the villagers had no jobs and were forced to go to the city for cheap labour but with the Indonesian decentralisation program, this village reorganised itself through community based social businesses. Its new elected leader gave inspirational leadership for community organising and they collectively took the theme of leaving no village behind. Through a string of collective businesses they found sustainable source of income and jobs for the village people which also strengthened their social solidarity.

Case study three is about rural China where the village people through e-commerce jump started their entry into online shipping. Supported by both private sector technology enablers and local government infrastructure support, the collective action by rural village committees has impacted household incomes as well as enabled traditional communities enter the modern markets.

These three case studies from three different Asian countries with sizable rural population is illustrative of what grassroots movements are doing in Asia. The show the dynamism, innovation, creativity, collective action and the potential of local communities when empowered are able to make a difference in the lives of families.

\section{CASE STUDY ONE: ASSOCIATION FOR SARVA SEVA FARMS (ASSEFA) THE INVISIBLE FORCE AT THE GRASSROOTS (MADURAI, INDIA)}

\section{Context}

The context of this Indian case study is Tamil Nadu which is in South India and it is one of the 28 states of India. In this state of Tamil Nadu there are 37 districts with an 
estimated population of 72 million people (Nadu, n.d.). Nearly 70 percent (Vezhaventhan \& Vanitha, 2018) of the total population live in the rural areas and are focused on agriculture.

India in general and Tamil Nadu in particular has taken rural development seriously with a major priority on agricultural development and local village development. Rural development is a comprehensive plan of action which seeks to improve the quality of life of ordinary people though improved infrastructure as well as connectivity. These facilities are well developed in cities but now there is an attempt to improve in rural areas too. The development priority is to "improve the social and economic condition of the people living in rural areas. It is the process, which improves the wellbeing and self-realisation of the people living beyond the urban areas. Rural development is a strategy by which change is brought among the rural people and the traditional way of living" (Thanikasalam \& Saraswathy, 2014). There are a number of key components that local government seeks to address in improving the quality of life of the rural people.

Village level governance is managed under the 'Panchayat' which is a system of village governance which has existed for a long time. Tamil Nadu has 12,524 Village Panchayats which is governed under the Tamil Nadu Panchayats Act, 1994 (Government Funds are allocated for local development, n.d.). This is a system of decentralised system of local governance at the village level relating to the district administration of the state. The focus of concern is multi-dimensional which includes agriculture and other village level economic development. This is undertaken through a democratic process of local people's participation in local level administration and prioritization of local needs. It looks at local development concerns at the village level including local infrastructure and local issues. Here the problems are identified and local solutions are proposed.

In addition "the promotion of rural entrepreneurship is vital in the context of generating gainful employment and minimising the widening of disparities between rural and urban population. For reducing poverty and to overcome low productivity in the farm sector rural entrepreneurship is necessary" (Vanitha \& Vezhaventhan, 2018)

In this context of rural entrepreneurship and rural development is the "white revolution' and the role played by co-operatives in dairy-development namely the growth of milk production and sales. One name that stands out in India, who is the architect of this revolution and who is also called the 'father of the white revolution' is Dr Verghese Kurien (Singh, 2018). His vision and task well documented in his book 'I too have a dream' 
(Parthasarathy, 1991) is about the empowerment of rural famers all over India. Dr Kurien's story was in Gujarat, however similar cooperative movements emerged elsewhere like in Tamil Nadu. Kurien's great lesson is his highlight of the role of ordinary people in managing their own collective action in a democratic way at the grassroots which is at the heart of the white revolution he created for India.

This case study is about the work undertaken by ASSEFA, India. It was founded by a Tamil person named S Loganathan who was influenced by both Mahatma Gandhi and Vinoba Bhave, who was a follower of Ghandi. The movement created at the village level is therefore rooted in Gandhian philosophy of Sarvodaya, which is the path of non-violence in building a society where equality and freedom of all human being is central. Therefore ASSEFA is following the Gandhian vision for rural development which is village level, decentralised approach where democracy, decision making and collective action enables them to undertake their own produce including cottage industries located in rural areas. ASSEFA started as a movement addressing the issue landlessness and securing land and in organising village farms.

\section{Location}

ASSEFA is operating in a number of States but with a major focus of the work is in Tamil Nadu. Its key coordinating centre is in Madurai city which is in the district of Madurai.

\section{Target Group}

ASSEFA is currently operating in 10,000 villages and touching the lives of more than $1,845,700$ rural families in Tamil Nadu. Majority of the rural folk are involved in the agricultural economy and are dependent on agriculture for their livelihood. Many people who are farmers are affected by insufficient water supply for farming and in some areas facing debts to moneylenders.

\section{Issues Encountered}


It is well documented that some of the problems faced by rural people are poverty, illiteracy, unemployment and problems related to agriculture. There are also issues pertaining to rural urban migration and this is due to lack of job opportunities in rural locations. In this context there real need is for "many problems such as the nourishment, illiteracy, unemployment and lack of basic infrastructure like schools, colleges, hospitals, sanitation" to be resolved. Young people are moving out of villages to work in cities. There is a need for rural to development and improve the services like urban areas especially the improvement of the standard of life.

\section{Innovations}

The first aspect of ASSEFA innovation is the philosophy and ideology which undergirds their community organising. The theme of "Sarvodaya is a model which is an ideal society to be founded upon non-violence, equity and freedom". The thrust is one on collective action at the village level. The principle of trusteeship is key "which provides a means by which the wealthy people would be the trustees that looked after the welfare of the people in general" (ASSEFA, 2018-2019).

Second, is the village development program, in creating a model village. ASSEFA at the village level undertakes a holistic range of interventions which encompasses improvement of the quality of life which incorporates health and hygiene, education, gender equality \& justice and community resources for sustainability.

Third, one of the effective economic and sustainable program at the village level is the dairy farms undertaken by families especially women in the care and milking of the cows. Each family with three to five milking cows producing milk daily is collected from the village and transported to a collection centre and then to the dairy cooperation milk processing plant. It is significant to note that "ASSEFA broke this monopoly of the government and promoted people-owned dairy societies. Milk processing plants and bulk cooling units were established in suitable locations, where surplus milks could be processed and marketed via well connected networks in retail or bulk under distinct brands like 'Seva' and 'Sarvodaya'. The first dairy plant was established in 1996 at Uchapatti village, near Madurai. Subsequently,

four more dairy plants were established in Natham, Pooriyampakkam, Gingee and Chinnasalem to provide integrated support to the dairy farmers" (ASSEFA, 2017-2018). 


\section{Organisation}

ASSEFA organisation can be seen at three levels one is at the village, the second is self-help organisation and finally the structuring of specific organisations with specific objectives. Legal structures established include cooperatives and mutual benefit societies.

At the grassroots level it's the village level organisation which is the Gram Sabha. At the village level the neighbourhood leadership committees are central. ASSEFA had introduced the village level leadership group especially in the formative period when addressing landlessness and ASSEFA's role in securing land for the grassroots. This was a Gandhian strategy of village level collective leadership structure. With State and government development of grassroots leadership, ASSEFA structures were dismantled so that its members and partners began to participate in the state sponsored local leadership \& governance schemes.

At the second level it is the role played by 27,000 self-help groups (SHG) of 20 women per group which is the grassroots organising of women. The SHG also undertake microfinance. The ASSEFA partners developed the SHG group approach in the early 1970 and 1980s. Tamil Nadu State agenda of SHG groups began in the 1990s. ASSEFA example was illustrative of what is possible as the grassroots.

At the level of specific organisations ASSEFA set up 160 organisation (Poirier \& Loganathan, 2019). Of these 113 are Mutual Benefit Trusts made up of women SHG, 9 Education Trust which manages schools and five milk processing organisations. ASSEFA has about 3,359 personal including full time, part time and consultants. Approximately $73 \%$ of them are women.

\section{Lessons Learnt}

Five key lessons can be learnt from the ASSEFA innovations. Some of these reflections were gathered in a discussion at a village near Madurai in Tamil Nadu in early $2020^{3}$.

\section{Differences in the economic model}

\footnotetext{
${ }^{3}$ Fifteen people gathered on Jan 10, 2020 at the ASSEFA Sathuragiri Campus at Ammapatti village about 33 kilometres south of Madurai city in Tamil Nadu. The discussion was very fruitful and was facilitated by ASEC President, Dr Denison Jayasooria from Malaysia
} 
The first lesson, centres on the question of what is the difference between dominant economic models with that of community based economies among ASSEFA partners?

Major differences cited is between the traditional businesses on the one hand and on the other the community approach of ASSEFA. Here it is the community nature and the socio-economic services undertaken which stand out. People's direct and active involved is the major difference between the two models. It is the collective ownership and running of the economy projects at the grassroots. The leadership is at the village, block and across villages through a federation of neighbourhood groups. These are people representatives at all levels. The other unique feature of ASSEFA are the beyond business and profit services such as local women empowerment including legal literacy and legal aid and other socio development projects such as health, education and local leadership development.

The ASSEFA involvement is a long-term commitment, ranging over 20 years of direct people to people participation at the village level for socio economic upliftment through selfhelp and resilience. It is therefore an agenda beyond just undertaking economic or income activities but twin approach of inclusive social development for all at the local community. The ASSEFA network of partners provide a collective set of assistance to grassroots communities such as leadership development, capacity building on specific crop or diary knowledge, collective marketing, financial loan availabilities and non-financial or banking activities.

\section{Women's participation in local economy}

The second lesson, is women participation especially at the grassroots by the self-help groups (SHG). These SHG is a collective organising at the neighbourhood village level by a group of 20 women and these groups are collectively organised as a federation. The leadership at both village and federation level are by the women themselves as they are organised as Chairman, CEO and accountant at the Federation level. While they undertake individual enterprise initiatives, however the distinctive feature is the collective decision making and accountability including access to credit and capability building programs. They noted that in the entrepreneurship and business activities undertaken there is an empowering process which is the handholding process of the people at the grassroots and also the continues undertaking of socio economic activities to enhance improved quality of life. 


\section{The achievements}

The third lesson, is with regards to the achievements made by the ASSEFA partners. The successful milk diary production is at each family level with each family owning 3 to 5 cows. There is collective milk collection, chilling and then sending to milk factory for processing. All these are organised by the local groups in a collective way. They are producing quality milk at fair and competitive prices. This is in a collective cooperative model as opposed to individual business or big business model. Here the producers are co-owners and not just passive producers. This approach is also applied to other agricultural and food producing crops. They have also organised farmers markets which is a regular feature at the rural level where farmers have an opportunity for direct sale of their products. In addition, water purification micro plants set up where drinking water could be purchased. These are all viable and profitable businesses at the village level.

The ASSEFA approach is to keep the local people in the village with self-employment prospects without having to leave the village for the urban slums in search for jobs. The participants also said they had no political advocacy role nor function as a pressure group on the political leadership at the local, State or National level. Their collective action has resulted in local empowerment and collective action for socio economic development. Their work as community builders has resulted in pioneering grassroots improvements which often is adopted by the State and local government including the political leadership due to their successful initiatives.

\section{The challenges encountered.}

The fourth lesson can be drawn from the challenges faced. Three major challenges and concerns can be highlighted. Challenge one: are the issues surrounding climate change and its impact on village life especially the planting of crops. Their main struggle is that there is no rain especially during the planting phase. If in one year the crop fails, local farmers are unwilling to risk another year doing the same. Therefore the challenge is how to plant less water dependent crops. This also raises the long-term investment by the State on irrigation systems at the village level. Crop and other educational literacy on new technology and agriculture is needed. 
Challenge two: due to climate failure and crop loses the debt level has risen. Many become victims to money lenders and alternative micro credit and financial literacy is most essential. ASSEFA provides such financial services and they need to build up their capacity in this area.

Challenge three: marketing and fair prices are key issues. It is noted that there is a lack of government support in this matter and a need for further support for food security matters as there is much local potential if there is greater public sector commitment to farmers.

\section{The way forward in SSE}

The fifth lesson can be found in the way forward. There is a need for climate change adoption. The key here is to reduce water dependency and choose other crops which do not need so much water. Farmers need awareness and mindset change for adoption of new ideas. This requires training, awareness, exposure and good illustrations of success in challenging weather conditions.

Encouraging young people to be involved in agricultural production is another major step forward in the future. However at the moment it is a major challenge. Currently young people are leaving the village for jobs in the urban centres and the long term sustainability of a workforce in the agricultural sector is a challenge. The campaign to get young people to stay in rural areas by improving the quality of life in the village and ensure better returns for their labour and investments.

\section{CASE STUDY TWO: PANGGUNGHARJO VILLAGE ENTERPRISES, JOGYAKARTA, INDONESIA}

\section{Context}

Indonesia is one of the fastest growing economies in South East Asia. Poverty has been reduced to $10 \%$ in 2017 . Its democratic reform has enabled the decentralisation of the governance structure. It has a sizable number of the population living in rural areas. It is $48 \%$ of the population which is about 120 million people. "Three out of five Indonesians live in rural areas and farming is their main occupation... agriculture contributes $8.5 \%$ to GDP... it is the main source of income for one third of the population and $64 \%$ of poor people" (IFAD). The major issues confronting the rural community is connectivity and infrastructure as these two areas are identified as the major challenges. 
The government of Indonesia in 2014 introduced a Village Law (No. 6/2014) with the aim "to promote greater participation of rural people in development processes, introduce more effective poverty reduction interventions and support improved local governance" (IFAD). Some features of this intervention strategy is helpful for ensuring overall socioeconomic improvements as well as strengthening local governance. Therefore livelihood activities according to village priorities ensure greater buy in and ownership of the economic ventures thereby improving productivity and returns.

The introduction of this new Village Law dramatically also increased the responsibilities and budgets of the village administration. "Villages receive large development grants from the state's budget of up to Rp. 1 billion (approximately US\$75,000). The responsibilities and powers of village heads and their staff will also receive a remarkable boost. Villagers are supposed to take a more active role in the public life of their villages. Such provisions potentially provide for a radical change of village life in Indonesia" (Berenschot \& Vel, 2017). This is referred to as the 'community driven development' and puts the development responsibilities on the local people.

The current Indonesian government under President Joko Widodo is also recognising the potential and challenges of rural Indonesia. They are now investing more in its development. The government has "identified and unveiled big plans around developing villages and improving connectivity" (Tanoto, 2015). This infrastructure development also has an impact on both the live hood and quality of life of the rural people. In addition the note that the Indonesian government has initiated economic programs for smallholder livelihood development as well as village development programme.

In this village of Panggungharjo it is the visionary leadership of the democratically elected local village leader which is significant. He is Wahyudi Anggoro Hadi and has been the elected leader since 2012 winning his third term in 2018 as the village leader. He is a pharmacist graduating from the Faculty of Pharmacy at Universitas Gadjah Mada. His activism is rooted in the university student movement as well as being part of Indonesia's largest Islamic organisation, the Nahdlatul Ulama (NU) and Movement of Indonesian Muslim Students. .

\section{Location}


The village of Panggungharjo, is located in the District of Bantul and in the Province of Jogyakarta. It is located at the outskirts of Yogyakarta and therefore have sub-urban characteristics which implies that the residents are well exposed to the city and outside influences. This village is one of the approximately 74,000 villages in Indonesia. Panggungharjo is divided into 14 sub-villages, with the southern areas being rural areas and the northern areas more urban areas.

\section{Target Group}

This is rural village close to the city of Jogyakarta. It is estimated that there are about 8,739 households with a village population of about 28,000. Unemployment is one major concern and many have to leave the village to seek employment in the city or in a nearby country as cheap labour. About 21.17 per cent are poor, and $44.49 \%$ per cent live slightly above the poverty line.

It is also noted that a “majority of Panggungharjo's residents are senior high school graduates; many have also had some tertiary education. The village is the site of several Islamic boarding schools, as well as some university campuses" (Bayo \& Santoso, 2019).

It is also documented that "many of its residents have abandoned agriculture and sought employment in other sectors. The majority of residents are private-sector employees (39\%) and labourers (38\%); only $4 \%$ of village residents (750 people) work in agriculture" (Bayo \& Santoso , 2019).There is a rise of the non-agrarian sectors including service, trade and industry including batik, statue, and furniture.

\section{Issues Encountered}

While employment was not a major issue for the well-educated within the village who found jobs in the nearby city, however it was the less educated in the community especially the informal, daily waged who faced many challenges and this aspect of livelihood and income support including job creation at the village level was one of the major local leadership priority.

Another major issue identified at the village level is money politics in the choosing of local village leaders and the dominance of the politics of patronage in which vote buying was rampant. This practice has a negative impact upon good governance and accountability at the 
village level. The village as a whole and candidates for village leadership had to set an alternative model to enhance democratic governance at the grassroots level.

\section{Innovations}

Panggungharjo village is one of the most successful villages in Indonesia wining many national level awards pertaining to good governance and local development agenda.

Many community based economic and business initiatives are integrated as collective village businesses for the common good. By integrated business they are able to work more efficiently, better serve and compete with other businesses without neglecting the social purposes such as job opportunities, equality, cultural identity and environmental sustainability. The village management system with citizen's participation has had a positive impact on the use of village funds for fostering the village economy. One major breakthrough at Panggungharjo are the initiatives to foster village level business enterprises. The local leadership fostered capacity building, and technical assistance through the establishment of new village enterprises (Badan Usaha Milik Desa). Called BUMDesa they have become sustained businesses initiatives at the ground level, contributing to the village economy as well as creating job creation opportunities. Two of the many community initiatives are highlighted here:

\section{Community based business project 1: Waste Management: KUPAS}

The formation of the Association of Waste Management Groups (Kelompok Usaha Pengelola Sampah, KUPAS) is a major innovation at the village level. A village-owned enterprise named Panggung Lestari was established. This was a waste management program and it involved local women's groups in collection and producing biodiesel. This is one aspect of local village women empowerment project generating income from the waste collection. It is documented that for Wahyidi, this is not only to "collect waste, but also as an extension of the village government, one responsible for directly dealing with residents, hearing their concerns, and identifying problems that required government involvement" (Bayo \& Santoso , 2019).

It provides employment for 26 of the village people and services over 1,700 families in this village. It provides dignity to work not garbage collectors but recycling \& proenvironment workers. It have changed the nature of waste collection. This is environment 
friendly and income generation, from 'waste to gold'. Furthermore, "this village-owned enterprise helped some 70 local residents deal with debts they had incurred with a loan shark, creating a Legal Aid and Human Rights Advisory Post” (Bayo \& Santoso , 2019).

\section{Community based business project 2: Community Restaurant at Kampong Mataraman}

This is the biggest of the community business projects which employ over 48 local people working this this restaurant. They are said to have over 500 customers (both tourist and locals) a day and they cater for meals like a family and community oriented restaurant.

It has a traditional design which gives the feeling of a traditional village house. Their local dishes are a typical of Javanese food and has a variety of local cuisines. It is displayed in tradition fashion in earthen pots with banner leaves. A popular tea time and dessert is fried banana. The community restaurant is well managed by a professional management staff from outside the community for her expertise. The staff are very friendly. There is this sense that they are not workers but owners of the business as the workers are all from the local village and have a great sense of pride to their work.

The land allocated by the village for this business venture is about 15 acres. In addition to halls with traditional design for meals there are also conference and seminar space available. There are plans to expand the services at this location to include home stay and handcraft sales.

\section{Organisation}

The village governance comes under the preview of the new Village Law (No. $6 / 2014$ ), the democratic election of the village leader as well as financial allocations from the government to manage local socio economic development. This is a democratic decentralised system of governance. The village level planning has taken into account community based businesses to provide job opportunities as well as income generation.

\section{Lessons Learnt}

Drawing from the Panggungharjo village experiences and innovations we can draw a number of lessons:

Firstly, the leadership quality of the local village leader. It is said that "Wahyudi made an important breakthrough in village-level politics by transforming clientelistic exchanges 
into programmatic ones. By implementing programmatic policies, Wahyudi created a new public ethos that positioned money not as an individual property, but rather something to be used for collective benefit. Ultimately, Wahyudi's programmatic policies were seen as fulfilling the community's needs. He created programmatic exchanges that transformed problems into solutions" (Bayo \& Santoso , 2019).

Secondly, we can note from Panggungharjo village, how the village broke money politics at the level of local village elections. This was done by breaking the cycle of supply and demand. It is noted that with the political reforms and a shift towards democratic governance in Indonesia there "exists a new political phenomenon, an anti-money politics movement that began at the grassroots, at the village level, the lowest level of government in Indonesia" (Bayo \& Santoso , 2019). In this context it is said the "practice of money politics cannot occur without the intersection of supply (from candidates) and demand (voters/constituents). To avoid the practice of money politics, it is thus necessary to disrupt these intersections" (Bayo \& Santoso , 2019). Researchers can verify that this "Indonesian village broke the chains of pragmatism and money politics by avoiding the practice of vote buying, rather than transforming itself to avoid corrupt practices" (Bayo \& Santoso, 2019).

The way this was undertaken was the leadership and personal example of the candidate for village leadership through his leadership initiative. "In this case, the candidate's actions were deeply rooted in his own background as an activist, as well as his efforts to dedicate himself to service and promote his values" (Bayo \& Santoso , 2019). In the case of Panggungharjo Village the researchers "found no evidence that vote buying had occurred in the village" (Bayo \& Santoso , 2019). It is further affirmed that "the victorious candidate did not use money politics to gain (or regain) office" (Bayo \& Santoso, 2019). The secret here is the "political leaders' use of programmatic policies and political representation to ... break the chains of money politics" (Bayo \& Santoso , 2019). It is therefore significant to note that "Wahyudi ... succeeded in shifting election discourse from 'vote for money' to 'vote for village development'. Lacking the financial capital of his competitor, he focused on policy and development issues" (Edi \& Wardhani, 2018).

Thirdly, we can recognise that the transformative leadership qualities of Pak Wahyudi Anggoro Hadi who is best guided by the governance structure in order for collective community identification of problems \& finding solutions. The principle is that no two villages are the same and due to decentralisation and the village autonomy principle, this 
particular village at Panggungharjo is able to make their own decisions on local development matters. There is therefore the instilling of the spirit of self-reliance and resilience. The village is entrusted to take care of itself within the village governance structure. This is facilitated by the role of self-help funds and mutual cooperation as a village colleective.

\section{CASE STUDY THREE: TAOBAO VILLAGE RURAL SERVICE CENTRES, CHINA}

\section{Context}

Out of 1.4 billion Chinese people, 39.2\% of them live in the rural areas (World Meter, 2020). This estimate of 800 million rural Chinese people is still a sizable population in comparison to global figures. Like other countries impacted with urbanisation, the rural areas needed renewal to reduce this trend of rural-urban migration. The Chinese Government introduced special programs to strengthen rural revitalization and renewal programs. Their national policy on "rural-urban integrated development" in an effort "to accelerate rural revitalization" (Wang \& Tan, 2018).

Over the past 30 years China has been experiencing rapid economic development. There are clear shifts in its economic model from "a centrally planned economy to a more market oriented system" (Association for Progressive Communications, 2019). This has had direct impact on poverty eradication programs. It is in this context of an open economy and China as one of the fast growing e-commerce market in the world, that the potential of ecommerce was recognised by the Alibaba group. In addition it was Alibaba which saw this as a real opportunity for rural China as a huge potential market (Wang J. , 2019).

The Alibaba group fostered the development of Taobao Villages among the rural population of China over the past 10 years ago. While Alibaba is a global operator in ecommerce it has played a major role in introducing e-commerce in rural Chinese village. It is observed by Jing Wang that "something unique is happening on both the consumption and business sides of rural e-commerce in China. A virtuous circle is taking place whereby ecommerce is enabling more rural residents to become entrepreneurs by selling local produce online, and the resultant income growth is driving up e-commerce based consumption as these rural residents seek out products they can't find in their neighbourhood stores (Wang J. , 2019)."

Alibaba launched in October 2014 its Rural Strategy (Rui \& Xie, 2018) to reach 1,000 County and reach 100,000 villages with the "goal of serving farmers, innovating agriculture, 
making the countryside better". There are many stories (CGTN, 2013) of young people returning from the cities to be close with their families in villages and working from ecommerce platforms linked to Taobao. Here they innovate to keep up with competition and on the whole these young people are earning as much as their counterpart in cities. They became juxtapose between the old rural China and at the same time interact with modern China through e-commerce.

\section{Location}

The Taobao Villages are located in rural China. There are a total of 1 million villages (Facts \& details)in China and each village has an average of 916 people. Over the past 10 years Taobao village number 4,310 in 25 provinces reaching over 250 million people (Facts \& details). This is an impressive growth and has had impact on the lives as well as rural economy in China.

A Taobao village is defined as one where "at least 10 percent of households engage in e-commerce (or where there are at least 100 active e-shops) with annual online sales of at least 10 million yuan (or \$1.5 million)" (World Bank Group \& Alibaba Group, 2019). Two of these Taobalo villages are cited in this review as examples namely the villages in Lin'an County and Sihong County.

\section{Target Group}

Rural people in China who are the people with limited options and access to products and services which city dwellers take for granted. They lack access to e-commerce and the digital economy. They do not own personal computers. If they want to purchase or sell they will have to rely on the village outlets or middle men or go directly to the closest city or urban centre. The rural areas are underdeveloped in comparison to the cities and urban centre.

\section{Issues Encountered}

One of the major issues was the people's transition from central planned economy towards a free market economy. This is not a mind-set change and cultural value change but also one of infrastructure needed to facilitate participation in the markets. However this was possible for rural people who did not have the skills or ownership of personal computers with 
the establishment of Taobao services centres in rural areas. Their adoption to this new economy was facilitated by both the State and private sector. With income generating opportunities opening up young people returned or reminded in the rural sector to engine this new transformation of the rural economy.

\section{Innovations}

Taobao has a business and social side. On the business side this e-commerce platform enables the villagers to sell their agricultural products, handcraft and manufactured goods and on the other enabled them through the e-commerce platforms to buy and shop on the net. This outlets called rural services centres or stations also became community meeting points for interaction and invocation in collectively addressing the modern challenges and opportunities as rural communities. These centres can be referred to as "larger ecological public welfare centres" (Rui \& Xie, 2018) due to the many kinds of services it provides beyond the business to incorporate the social networks of the family and local community.

An example of a Taobao Rural Service Centre is at Gonjiva village in Lin'an County in Zhejiang Province (Alibaba Group, 2015). The centre is operated by Ms Gong Jianfei who lives in this village and was assisted by Alibaba in setting up this centre. The set up of the centre and the space is with the cooperation of the local government. Alibaba provides the computer, big screen TV, technical support and training. Ms Gong is the online shopper for the whole village as majority do not have computers or smart phones. There is therefore cooperation among the villagers. The villagers come in to this centre and make their orders for all kinds of goods they like to purchase like cloths and house hold items. They also make payments for online services such as purchases travel tickets, payment of utility bills and even topping of phone credit. Previously the villagers would have to go to the town but now they can do all on line. The Rural Service Centre has also become a hangout place for local residents. The centre is open from 7.30am till evening and there is about 40 to 50 transactions a day. Ms Gong gets a salary from the village and also earns a commission from the sales. Alibaba provides the logistics supports of transportation to and from the village which might take between 2 to 7 days. There is work in progress for local farmers to sell their produce on line.

Another example of a Rural Service Station in Mudan Island (Alibaba Group) in Sihong County which is a small water locked community and the nearest town is Bancheng 
Town and its a 25 minutes boat ride. Villages have to travel to make simple purchases such as cooking oil, washing soap and other basic necessities, as there are no retail shops on the island. Therefore when the station was established, local people were delighted. Here too, Alibaba worked with the local government and local community to establish this station. $\mathrm{Mr}$ Tian Qian Chun who is local born is the operator. He like many youths returned from the city back to the village due to the rural e-commerce program. Services provided are similar to that of Gonjiva village. The villages wanted to sell their agricultural produce to the people outside the island. This station was given a facelift by funding from the government to subside the cost of redesigning the station. The community collectively also tapped the tourist potential with the many scenic spots on Mudun Island. This station now serves as a bridge between the village people with the outside world.

\section{Organisation}

This initiative of Taobao Rural Service Centres or stations is not a single project in one location but over 4,000 such centres in rural villages around China. It is set up with the cooperation of the local government, local village committee and the private sector technical and logistical support namely Alibaba. Each operates independently but share the digital platforms and infrastructure. It is sustained by the collective support of the village people who are part of this enterprise and who see the value and utilise the services. At the heart of the project is a full time coordinator who is paid by the village as well as receives commissions for the online transactions. He/she also receives technical and logistical support from Alibaba team.

\section{Lessons Learnt}

This rural revitalization project is indeed innovative and contemporary. We recognise that the rural revitalization program has the support of the government, private sector and local communities. While it was driven by the private sector it would have not been possible to make such advances if not for the strong support of both the State and the local community.

We can note that in China there is the "government led rural renewal program" as well as "the self-organised rural renewal program" (Wang \& Tan, 2018). This case study draws from the later which is the power of local communities to innovate in a changing economic context. Rural China has a collective leadership structure where solidarity based economic 
projects such as collective farms and production was the way. However with the shift towards market orientation individual farms and production began with collective cooperation for comparative advantage. In this context the e-commerce gave unlimited opportunities for rural communities. This is truly a transformation from physical to digital economy.

We can also observe that the inclusive economic growth model via "e-commerce in rural areas has ...led to higher household consumption....reduced inequality and better job opportunities for women and young people" (Wang J. , 2019). Furthermore "e-commerce enables all merchants to display their products online on an equal footing no matter where they are and whether their business is big or small. Merchants doing small business or living in remote areas can also stand out as long as they sell high-quality or creative products." The growth in e-commerce is increasing the number of people in villages to remain at home and earn a living. This is reducing the rural -urban migration and at the same time developing rural economy.

\section{CONCLUSION}

In this review of three grassroots examples from three different countries in Asia we can note that the grassroots communities are dynamic on the ground. They are looking for more than handouts but they have the resilience to respond to the market, health and climate shocks in all three countries. It is the catalyst leader in local village as in Indonesia or an innovative cooperative organiser as seen in India or a visionary private sector investor as in China. They each saw the need to mobilise the grassroots as a movement of people not just individual actors. The spirit of solidarity and collective cooperation is imperative for their success at the local, district or national levels. People as the drivers of community based initiatives and they could also be the beneficiaries.

Individuals, families and communities found ways of creating wealth in the rural areas by rejuvenating the economy and not by abounding it. In the case of India the women organised themselves as self-help groups and got directly involved in dairy production, with 3 to 5 milking cows they are able to have a comfortable source of income in the village. In the case of Indonesia they set up community businesses which not only provided a service but also jobs for many locally. In the Chinese example we saw how the traditional economy was fast tracked into the digital economy through e-commerce with buying and selling on line 
which was supported by the private sector transforming the rural areas into economic growth hubs.

We can therefore call on policy makes to rethink development planning and give equal weight to the rural as they do to the urban and in doing so they will be enable to rebuild rural communities which can be strategic for food security and enable the nation to reach food sufficiency. Relocating industries to the rural areas might also make an impact upon rural urban migration. The way forward is to ensure the quality of life and services in the rural areas are as developed as the urban. This will provide the citizens a good chance to decide on their future. Asians at the grassroots are showing their governments that there is still hope for the rural and therefore in the words of Pak Wahyudi of Indonesia 'Jangan tinggalkan desa' meaning do not let the rural area be left behind ${ }^{4}$.

\section{REFERENCES}

Alibaba Group. Taobao Rural Service Center. 2015. Retrieved from Youtube: https://www.youtube.com/watch?v=_QAdgZqEOfc

Alibaba Group. Taobao Rural Service Brings E-commerce to Mudan Island. 2016. Retrieved from Youtube: https://www.youtube.com/watch?v=Hst9bMu42uI

ASEC. Revitalising rural economy, through \& to Social Solidarity Economy. 2019. Retrieved from Socio Eco: http://www.socioeco.org/bdf_colloque-22_en.html

ASSEFA. ASSEFA Annual Report. 2018. Retrieved from http://www.assefa.org/wpcontent/uploads/2019/05/Annual_report_2017-18.pdf

ASSEFA. Report on ASSEFA experiences for the last five decades. Released at the ASSEFA 50th Anniversary. 2019.

Association for Progressive Communications. Where community networks may not go: ecommerce claims to bridge the rural-urban gap in China. 2019. Retrieved from Rising Global Voices: https://rising.globalvoices.org/blog/2019/02/22/where-community-networksmay-not-go-e-commerce-claims-to-brid

Bayo , L. N., \& Santoso , P. Breaking the Chains of Transactionalism: A Village Election without Money Politics in Panggungharjo. 2019. Retrieved from https://jurnal.ugm.ac.id/pcd/article/view/52726/26572

Berenschot, W., \& Vel, J. New Law, New Villages? 2017. Retrieved from Inside Indonesia: https://www.insideindonesia.org/new-law-new-villages-2

\footnotetext{
${ }^{4}$ This is the title of a book written by Wahyudi Anggoro Hadi the village leader which was published in 2018 in
} the Indonesian Malay language. 
CGTN. E-commerce boosts China's rural economy. 2013. Retrieved from Youtube: https://www.youtube.com/watch?v=MEhd92DkIVM

Edi , A. C., \& Wardhani, I. S. Transformational and Transactional Leadership Understanding How Leadership Cultivates Democratic Citizenship in Panggungharjo, Bantul, Yogyakarta. 2018. Retrieved from https://jurnal.ugm.ac.id/pcd/article/view/35229

Facts $\&$ details. (n.d.). Retrieved from Facts \& details: http://factsanddetails.com/china/cat11/sub72/item1088.html

Government Funds are allocated for local development. (n.d.). Retrieved from Government of Tamil Nadu: https://tnrd.gov.in/schemes/st_thai.php).

IFAD. (n.d.). Investing in Rural People in Indonesia. Retrieved from International Fund For Agricultural Development: https://www.ifad.org/documents/38714170/39972509/Investing+in+rural+people+in+Indones ia.pdf/70e8e737-5a47-4826-89db-de5c60da6c02

Nadu, G. o. (n.d.). History and Geography. Retrieved from Government of Tamil Nadu: https://www.tn.gov.in/tamilnadustate.

Nair, C. A call to reverse urbanisation in Asia. 2013. Retrieved from https://www.ft.com/content/28967fd6-9238-11e2-851f-00144feabdc0

Parthasarathy, G. White Revolution, Dairy Co-operatives and Weaker Sections. 1991. Retrieved from Economic \& Political Weekly: https://www.epw.in/journal/1991/52/reviewagriculture-uncategorised/white-revolution-dairy-co-operatives-and-weaker

Poirier, Y., \& Loganathan, K. Association for Sarva Seva Farms ( ASSEFA) India: 50 years of Sustainable Development. 2019. Retrieved from http://unsse.org/knowledgehub/association-for-sarva-seva-farms-assefa-india-50-years-of-sustainable-development/

Rui , O., \& Xie, C. Case study: Rural Taobao Service Station, Mudun Island. 2018. Retrieved from https://www.ceibs.edu/alumni-magazine/case-study-rural-taobao-service-station-mudunisland

Singh, M. K. White Revolution 3.0? 2018. Retrieved from The Economic Times: https://economictimes.indiatimes.com/news/economy/agriculture/white-revolution-30/articleshow/66794515.cms?from $=\mathrm{mdr}$

Steiner, A., \& Fan, S. (n.d.). Rural areas are in crisis. Revitalization is the solution. Retrieved from News Trust: https://news.trust.org/item/20190326150827-0ryhf

Tanoto, A. Why Rural Indonsia Is Ripe For Investment? 2015. Retrieved from We Forum: https://www.weforum.org/agenda/2015/04/why-rural-indonesia-is-ripe-for-investment/

Tay, K. S. Beyond the countryside: The urban/rural divide. 2008. Retrieved from Global Asia: https://www.globalasia.org/v3no3/cover/behold-the-countryside-the-urban-ruraldivide_kheng-soon-tay 
Thanikasalam, S., \& Saraswathy, S. Role of Gram Panchayat in Rural Development: A study of Vagurani Village of Usilampatti Block of Madurai District ( Tamil Nadu). 2014. Retrieved from http://www.ijhssi.org/papers/v3(1)/Version-2/I03102049056.pdf

Vanitha, D., \& Vezhaventhan, D. A Study on Rural Development in Tamil Nadu. 2018. Retrieved from https://acadpubl.eu/hub/2018-120-5/5/406.pdf

Wang, J. Taobao villages driving 'Inclusive growth' in rural China. 2019. Retrieved from https://www.alizila.com/taobao-villages-driving-inclusive-growth-rural-china

Wang, R., \& Tan, R. Rural Renewal of China in the context of Rural-urban integration: Governance Fit and Performance Differences. 2018. Retrieved from Research Gate: https://www.researchgate.net/publication/323245525_Rural_Renewal_of_China_in_the_Cont ext_of_Rural-Urban_Integration

World Bank Group \& Alibaba Group. E-Commerce Development, Experiences from China. 2019. Retrieved from http://documents.shihang.org/curated/zh/823771574361853775/pdf/Overview.pdf World Meter. World Meter. 2020. Retrieved from https://www.worldometers.info/worldpopulation/china-population/

Recebido em 17 de Julho de 2021

Aprovado em 28 de novembro de 2021

Publicado em 07 de fevereiro de 2022 